\author{
Marija Pleić, PhD, Assistant Professor \\ University of Split, Faculty of Law \\ Domovinskog rata 8, 21000 Split, Croatia \\ marija.pleic@pravst.hr
}

\title{
CHALLENGES IN CROSS-BORDER TRANSFER OF PRISONERS: EU FRAMEWORK AND CROATIAN PERSPECTIVE $^{1}$
}

\begin{abstract}
Framework Decision 2008/909/JHA on the application of the principle of mutual recognition for judgments imposing custodial sentences or measures involving deprivation of liberty is an EU instrument intended to facilitate the transfer of prisoners between the EU members, allowing at the same time the possibility of the transfer without the prisoner's consent. Even though the purpose of this instrument, as stated in recital 9, is to facilitate the social rehabilitation, its application can raise questions regarding the fulfilment of this goal and regarding the protection of the fundamental rights in the transfer proceedings. That has been recognised on the EU level, hence research and analysis of the implementation of FD 909 have recently been conducted, especially concerning the detention conditions across the EU and limits to the mutual trust presumption in the light of the CJEU judgement Aranyosil Căldăraru.

The paper analyses some key issues regarding the application of the principle of mutual recognition in this area: possibilities of social rehabilitation of the sentenced person, procedural rights in the transfer proceedings, possible violations of the prohibition of torture, inhuman and degrading treatment due to inadequate detention conditions in the executing member state. The paper also analyses the connection between this Framework decision and the Framework decision on the European arrest warrant. The special attention is given to the relevant jurisprudence of the Court of Justice of the EU. Along with the EU framework, the paper provides an overview of the Croatian legislation and jurisprudence regarding the mentioned subject.
\end{abstract}

Keywords: European arrest warrant, mutual recognition, social rehabilitation, transfer of prisoners

\section{INTRODUCTION}

Within the framework of the third pillar, the EU undertook more intensified legislative activities relating the area of detention in 2008 with the adoption of the instrument of mutual recognition of custodial sentences and measures involv-

This article is a product of work that has been supported by the Croatian Science Foundation under the project 8282 'Croatian Judicial Cooperation in Criminal Matters in the EU and the Region: Heritage of the Past and Challenges of the Future' (CoCoCrim) 
ing the deprivation of liberty. This was preceded by the adoption of the first and most important instrument of mutual co-operation in criminal matters between the EU member states: the Framework Decision on the European Arrest Warrant in 2002. ${ }^{2}$ After FDEAW, a package of coherent and complementary framework decisions was adopted in 2008: ${ }^{3}$ Council Framework Decision 2008/909/ JHA on the application of the principle of mutual recognition to the judgments imposing custodial sentences or measures involving the deprivation of liberty, ${ }^{4}$ Council Framework Decision 2008/947/JHA on the application of the principle of mutual recognition of probation decisions and alternative sanctions, ${ }^{5}$ Council Framework Decision 2009/829/JHA on the application of the principle of mutual recognition to the decisions on supervision measures as an alternative to provisional detention. ${ }^{6}$ The application and functioning of these instruments, especially of the European Arrest Warrant, raised the question of relationship between the principle of mutual trust and the protection of fundamental human rights of persons concerned, especially the rights guaranteed under Article 4 of the Charter of Fundamental Rights of the European Union (CFREU). ${ }^{7}$ This issue has been emphasised and discussed as a result of the situation in the prison systems in some EU member states (MS) which led to the systematic violations of Art. 3 of the European Convention on Human Rights and Fundamental Freedoms (ECHR) established in the jurisprudence of the European Court of Human Rights (ECtHR).

Focus of this paper is on the Framework decision on the transfer of prisoners. Although almost 10 years have passed since it was adopted, given the implementation deadline and the practical experience of the MSs, the effects of its application can be seen and analysed only up until recently. Furthermore, the Court of Justice

2 Council Framework Decision 2002/584/JHA of 13 June 2002 on the European arrest warrant and the surrender procedures between Member States [2002] OJ L 190 (FDEAW)

3 Report from the Commission to the European Parliament and the Council on the implementation by the Member States of the Framework Decisions 2008/909/JHA, 2008/947/JHA and 2009/829/JHA on the mutual recognition of judicial decisions on custodial sentences or measures involving deprivation of liberty, on probation decisions and alternative sanctions and on supervision measures as an alternative to provisional detention, $\operatorname{COM}(2014) 57$ final, Brussels, 5.2.2014 p. 5

https://eur-lex.europa.eu/legal-content/EN/ALL/?uri=celex\%3A52014DC0057] Accessed 10 April 2018

4 Council Framework Decision 2008/909/JHA on the application of the principle of mutual recognition to judgments imposing custodial sentences or measures involving deprivation of liberty [2008] OJ L 327 (FD on transfer of prisoners)

5 Council Framework Decision 2008/947/JHAon the application of the principle of mutual recognition of probation decisions and alternative sanctions [2008] OJ L 337

6 Council Framework Decision 2009/829/JHA on the application of the principle of mutual recognition to decisions on supervision measures as an alternative to provisional detention [2009] OJ L 294

7 Charter of Fundamental Rights of the European Union [2012] OJ C 326 (CFREU) 
of the European Union (CJEU) in 2106 delivered the first judgement relating to the interpretation of FD on the transfer of prisoners in Ognyanov case ${ }^{8}$ (regarding the law governing the enforcement of the sentence) and two more judgements in 2017, Grundza9 (interpretation of the condition of double criminality) and van $V_{e m d e} e^{10}$ (interpretation of the concept of 'issue of the final judgment' under the transitional provision).

\section{TRANSFER OF PRISONERS WITHIN EU}

\subsection{Key issues regarding the Framework decision on the transfer of prisoners and its implementation}

Framework Decision on transfer of prisoners is an EU instrument intended to facilitate the transfer of prisoners between the EU member states superseding other international legal instruments in this area. ${ }^{11}$ The most arguable issue under this document in relation to earlier legislation is the introduction and extension of the possibilities of the transfer without the prisoner's consent.

This FD should have been implemented by 5 December 2011, but only five MSs have transposed it into national legislation by that date, and in 2014, two years after the implementation date, $10 \mathrm{MSs}$ still did not transpose it. Today, the implementation of this instrument is still ongoing in Bulgaria, whereas all other MSs have transposed it. ${ }^{12}$

The principle of mutual recognition, inter alia, aims to enhance the protection of individual rights and to facilitate the process of rehabilitating offenders, and this FD purports both of these tendencies by declaring social rehabilitation as a main purpose of this instrument (Article 3(1)) and by observing the obligation to

\section{C-554/14, Atanas Ognyanov [2016] ECLI:EU:C:2016:835 \\ C289/15, Jozef Grundza [2017] ECLI:EU:C:2017:4 \\ C582/15, Gerrit van Vemde [2017] ECLI:EU:C:2017:37}

11 It replaces the European Convention on the transfer of sentenced persons of 1983 and the Additional Protocol thereto 1997; the European Convention on the International Validity of Criminal Judgements of 1970; Title III, Chapter 5 of the Convention of 1990 implementing the Schengen Convention of 1985 on the gradual abolition of checks at common borders; and the Convention between the Member States of the European Communities on the Enforcement of Foreign Criminal Sentences of 1991. Working Group Report, 9 May 2016, Brussels, Belgium, EuroPris FD 909 Expert Group, p. 5, http://www.europris.org/file/europris-framework-decision-909-expert-group/] Accessed 29 March 2018

12 European Judicial Network, Status of implementation of Council Framework Decision 2008/909/ JHA of 27 November 2008, https://www.ejn-crimjust.europa.eu/ejn/EJN_library_statusOfImpByCat.aspx?CategoryId=36] Accessed 29 March 2018 
respect the fundamental rights (Article 3 (4)). Nevertheless, in some situations, the unreserved application of the principle of mutual recognition to custodial sentences and measures involving the deprivation of liberty can raise problems in relation to these two tendencies, i.e., it can hinder social rehabilitation and the protection of fundamental rights. The report of the Commission on the implementation of FDs related to detention, ECtHR and CJEU case law, as well as some research studies revealed and highlighted some problematic issues in that direction, regarding the problems of non-consenting transfer, material detention conditions and violation of Article 4 CFREU, sentence execution modalities and implementation modalities. ${ }^{13}$ In view of the above, some of the detected issues in the implementation of this FD will be analysed in the following chapters.

\subsection{Overview of the Croatian legislation on the transfer of prisoners}

FD on the transfer of prisoners was transposed into the legal order of the Republic of Croatia through the Act on Judicial Cooperation in Criminal Matters with Member States of the European Union (hereinafter: Act on Judicial Cooperation) in 2013. ${ }^{14}$ Title VII of the Act regulates the recognition and enforcement of judgments imposing custodial sentences or measures involving the deprivation of liberty.

County courts are deemed competent authorities for the transfer decisions. The county court covering the territory where the person concerned resides or is domiciled, or alternatively, where the family of the sentenced person resides or is domiciled, is competent and responsible for receiving the decisions of foreign judicial authorities. The county courts are also competent for forwarding a judgment in the case of decisions issued by the same court and those issued by municipal courts within their territorial jurisdiction.

Article 89 requires that for the recognition of a judgement imposing a custodial sentence condition of double criminality be met for all criminal offences. ${ }^{15}$ The Republic of Croatia notified the General Secretariat that it would not apply Article 7 (1) of FD which enables the recognition of a judgement without the verifica-

13 Meysman, M., Council Framework Decisions 2009/829/JHA, 2008/909/JHA and 2008/947/JHA and their implementation: state of play and overcoming legal and practical problems, Academy of European Law -Improving conditions related to detention The role of the ECHR, the Strasbourg court and national courts, 25-26 February 2016, Strasbourg, ERA, p. 4, [https://biblio.ugent.be/publication/7136169] Accessed 26 April 2018

14 Act on Judicial Cooperation in Criminal Matters with Member States of the European Union, Official Gazette 91/10, 81/13, 124/13, 26/15, 102/17

15 Cf. Garačić, A., Zakon o pravosudnoj suradnji u kaznenim stvarima s državama članicama Europske unije u sudskoj praksi, Rijeka, 2015, p. 333 
tion of double criminality for the catalogue of 32 criminal offences. ${ }^{16}$ Nonetheless, when deciding on the recognition of a judgement, the courts refer to Art. 10 of the Act as a general provision which excludes the verification of double criminality for the catalogue of 32 criminal offences. ${ }^{17}$

The Croatian legislator implemented the possibility of transfer without the consent of the sentenced person in accordance with the provisions of FD. However, in terms of the grounds for the refusal of recognition, the Act on Judicial Cooperation distinguishes mandatory and optional grounds despite the fact that FD on the transfer of prisoners, unlike FDEAW, introduces only optional grounds for non-recognition and non-enforcement of the decision. ${ }^{18}$

The amendment to the Act of 2015 prescribed the obligatory detention of the person located within the territory of the Republic of Croatia when deciding on the recognition of a foreign judgement imposing a custodial sentence of five years or a more severe punishment, and thus resolved the doubts that existed in the practice regarding the application of Art. 123 (2) of the Criminal Procedure Act. ${ }^{19}$

Some specific issues regarding the national legislation and practice on the transfer of prisoners will be analysed further in the paper.

\section{SOCIAL REHABILITATION IN THE FOCUS OF FD 909}

\subsection{Social rehabilitation as the main purpose of FD 909?}

Social rehabilitation of the sentenced person is placed into focus of FD 909 as its main goal and the leading principle. ${ }^{20}$ However, this instrument of judicial coop-

16 Notification by Croatia on the implementation of the Framework Decision on Transfer of prisoners, 12335/14, Brussels, 17 September 2014,

https://www.ejn-crimjust.europa.eu/ejn/libdocumentproperties.aspx?Id=1386] Accessed 26 April 2018

17 Krbec, I., Priznanje i izvršenje stranih odluka prema Zakonu o pravosudnoj suradnji u kaznenim stvarima $s$ državama članicama Europske unije, Hrvatski ljetopis za kazneno pravo i praksu (Zagreb), vol. 21, broj 2/2014, p. 417. In case Grundza CJEU stated that the condition of double criminality must be considered to be met, in a situation where the factual elements underlying the offence, as reflected in the judgment handed down by the competent authority of the issuing State, would also, per se, be subject to a criminal sanction in the territory of the executing State if they were present in that State. Grundza, par. 55

18 See Klimek, L., Mutual Recognition of Judicial Decisions in European Criminal Law, Springer, 2017, p. 290

19 Criminal Procedure Act, Official Gazette 152/2008, 76/2009, 80/2011, 91/2012, 143/2012, 56/2013, 145/2013, 152/2014, 70/2017. Cf. Krbec, op. cit. note 18, p. 434

20 Number of the FD's provisions invoke this aim (Recital 9, Articles 3, 4(2), 4(4)) 
eration, as some authors emphasised, contains some elements that are contrary to the philosophy of reintegration. ${ }^{21}$

Firstly, the transfer under this FD is by its nature a quasi-automatic instrument, i.e., not dependent on anything else but the decision of the initiating member state (MS). ${ }^{22}$ Both the executing state and the sentenced person can request the initiation of the transfer proceedings but it does not impose any kind of obligation on the issuing state to initiate the procedure and forward the judgement to the executing state (Art. 4(5)). Some researches pointed to the inconsistencies in the national legislations even in relation to the possibility of initiating the procedure. ${ }^{23}$ Although the issuing state, before it decides to forward the judgement, should be satisfied that the transfer will serve the purpose of facilitating social rehabilitation, there is no mechanism of control over the assessment of the issuing state as to whether the transfer would actually serve this purpose. The executing state may, during consultations with the issuing state, present the competent authority of the issuing state with a reasoned opinion that the enforcement of the sentence in the executing state would not serve aforementioned purpose. This opinion can be a reason for the withdrawal of the certificate by the issuing state but, as it is explicitly stated (recital 10), it does not constitute the grounds for the refusal of social rehabilitation.

More disputable issue regarding the aim of facilitating the social rehabilitation is the fact that FD provides for the possibility of the transfer without consent of the sentenced person. ${ }^{24}$ According to Art. 6, non-consenting transfer is possible to the state of nationality in which the sentenced person resides, to the state to which he or she will be deported when released upon the enforcement of the sentence and to the state to which he or she has fled or otherwise returned.

It is argued that the interest of the member states in reducing the costs is the main reason behind the rhetoric of this FD on providing the best possible opportuni-

${ }^{21}$ De Wree, E., Vander Beken, T., Vermeulen, G., The transfer of sentenced persons in Europe: Much ado about reintegration, Punishment Society, 2009, 11, p. 124

22 De Bondt, W., Suominen, A., State Responsibility When Transferring Non-consenting Prisoners to Further their Social Rehabilitation - Lessons Learnt from the Asylum Case Law, European Criminal Law Review, 5(3) 2016, p. 357

23 Marguery, T., Part VI Conclusions and Recommendations, in Marguery, T. (ed), Mutual Trust under Pressure, the Transferring of Sentenced Persons in the EU, Transfer of Judgments of Conviction in the European Union and the Respect for Individual's Fundamental Rights, 2018, p. 8,

https://euprisoners.eu/wp-content/uploads/sites/153/2017/11/EUPrisoners-Part-VI-Conclusions-and-recommendations.pdf] Accessed 26 April 2018

24 Additional Protocol to Convention on transfer of Sentenced Persons provided for the non consenting transfer in limited circumstances but it was not ratified by all EU MS. See Klimek, op. cit. note 20, p. 278 
ties for social reintegration of the sentenced person. The efforts for resocialisation which take place against the will of the individual have only minor prospects for success ${ }^{25}$ According to a research study, the prisoners perceive transfer as beneficial only if it contributes to the reduction of their incarceration time, and family relations (as a relevant element for the enhancement of social rehabilitation) are listed as a second argument for transfer. ${ }^{26}$ The problem of achieving this aim is even greater if considered in the context of inadequate detention conditions in some EU MSs which can lead to the violation of Article 4 CFREU. ${ }^{27}$

Art. 103 (2) of the Croatian Act on Judicial Cooperation defines social rehabilitation as the main purpose but it does not set forward any specific criteria on the factors relevant for the assessment of this purpose when deciding on forwarding the judgement. ${ }^{28}$ However, it prescribes the elements that should be taken into consideration by the Ministry of Judiciary in cases when the consent of the Ministry for the recognition of the judgment is required: if the sentenced person or members of his or her family have domicile/residence in the Republic of Croatia, if he or she owns any intangible property in the Republic of Croatia, and any other personal and social circumstances that link the sentenced person to the Republic of Croatia.

\subsection{Enforcement of the sentence}

One of the most important issues of the transfer of prisoners is the question of law applicable to the enforcement of the sentence. The modalities of the enforcement of the sentence, i.e. the possibilities of the remission of the sentence depend on these rules, and this can be a decisive element for the issuing state when deciding on forwarding the judgement. These elements, especially the rules on early and conditional release, are the key factors in assessing the benefits of the prisoner's

25 Ambrož, M., Transfer zapornikov znotraj EU - res v imenu socialne reintegracije? Revija za kriminalistiko in kriminologijo, Ljubljana, 63, 2012, issue 3, p. 197

26 Durnescu, I., Montero Perez de Tudela, E., Ravagnani, L., Prisoner transfer and the importance of 'release effect, Criminology \& Criminal Justice Vol 17, Issue 4, pp. 450 - 467,

http://www.cep-probation.org/paper-prisoner-transfer-and-the-importance-of-release-effect/] Accessed 26 April 2018

27 Infra 5.1.

28 See European Union Agency for Fundamental Rights, Country study for the project on Rehabilitation and mutual recognition - practice concerning EU law on transfer of persons sentenced or awaiting trial Croatia, May 2015, p. 15,

[http://fra.europa.eu/sites/default/files/fra_uploads/criminal-detention-country_hr.pdf] Accessed 26 April 2018 
transfer. Therefore, they should be fully informed on the legal consequences of the transfer. ${ }^{29}$

European Commission recognised the difference between MSs' laws on the enforcement of custodial sentences as a potential obstacle for the successful functioning of the Framework Decision. ${ }^{30}$ The problem may occur when the executing MS has a more lenient system of enforcement of sentence, especially the system of early release, than the issuing MS. ${ }^{31}$

FD on the transfer of prisoners in Art. 17 specifies that the procedures for the enforcement of the sentence including the grounds for early or conditional release are governed by the law of the executing State. This raises the question of the division of competences between the issuing and the executing MS. ${ }^{32}$

CJEU had the opportunity to interpret this provision for the first time in $O g$ nyanov case. ${ }^{33}$ The referring court asked CJEU whether this article permits the executing state to grant the sentenced person remission of his sentence on account of work he has done while being held in detention in the issuing state although the competent authorities of the issuing State did not, in accordance with the law of that state, grant such a reduction of the sentence. ${ }^{34} \mathrm{CJEU}$ concluded that "the law of the executing state can apply only to the part of the sentence that remains to be served by that person, after that transfer, on the territory of the executing State." ${ }^{35}$ According to the Advocate General Bot's opinion, the executing state cannot substitute its own laws on the enforcement of sentences with those of the issu-

29 Cf. Ddamulira Mujuzi, J., The Transfer of Offenders between European Countries and Remission of Sentences: A Comment on the Grand Chamber of the Court of Justice of the European Union's Judgment in Criminal Proceedings against Atanas Ognyanov of 8 November 2016 Dealing with Article 17 of Council Framework Decision 2008/909/JHA, European Criminal Law Review, Volume 7 (2017), p. 301

30 European Commission, Strengthening mutual trust in the European judicial area - A Green Paper on the application of EU criminal justice legislation in the field of detention, COM (2011) 327 final, Brussels, 14.6.2011, p. 6,

http://eur-lex.europa.eu/legal-content/EN/TXT/?uri=CELEX:52011DC0327] Accessed 26 April 2018

31 Ibid.

32 Case C-554/14, Atanas Ognyanov, Opinion of Advocate General Bot [2016] ECLI:EU:C:2016:319, par. 143 - 150. See Montaldo, S., Judicial Cooperation, Transfer of Prisoners and Offenders' Rehabilitation: No Fairy-tale Bliss. Comment on Ognyanov, European Papers, Vol. 2, 2017, N0 2, p. 712

http://www.europeanpapers.eu/en/europeanforum/judicial-cooperation-transfer-of-prisoners-offenders-rehabilitation-comment-on-ognyanov] Accessed 26 April 2018

33 Ognyanov case, par. 54-70

34 Ibid., par. 30

35 Ibid., par. 40 
ing state, even if its own legislation is more favourable to the person concerned. ${ }^{36}$ Despite the fact that this FD has not been implemented in the national law, it supersedes the national law even if the national law is more lenient towards the offender. ${ }^{37}$

Some authors argue that the decision not to take into account the time spent working in the issuing MS, and therefore, not to consider the law of the executing MS, could be interpreted as contrary to Art. 17(1). ${ }^{38}$ But, in the context of this case one must not overlook the fact that the authorities of the issuing MS expressly stated that their law did not permit the reduction of sentence on those grounds. ${ }^{39}$ Reducing the sentence in situation like this could deter MSs from transferring the prisoners to some other MSs and thereby defeat the objective of prisoner transfer. ${ }^{40} \mathrm{AG}$ Bot stressed that the focus on the remission of sentence at issue should not obscure the fact that Mr Ognyanov's transfer is in itself intended to be more favourable to him, in terms of his social rehabilitation. ${ }^{41}$ Even though AG correctly stated that serving the sentence within the prisoner`s own social environment favours social rehabilitation, we must not ignore the fact that, in the prisoner's perspective, the real duration of sentence is a very important element as well. In regard to the transfer without consent and without taking into account the prisoner's opinion, the achievement of the aim to enhance social rehabilitation in case of the "forced transfer" of the prisoner to the executing state with a more stringent system of enforcement of sentence (early release) is indeed questionable.

According to Art. 17(3), the issuing state must be informed, upon its own request, about the applicable provisions on a possible early or conditional release, and if it does not agree with these provisions, it may withdraw the certificate. If the issuing state does not request to be informed, it can be assumed that it accepts the modalities of the enforcement of the sentence in the executing state. On the other hand, the absence of the request can raise the question over the real reasons behind the issuing state's decision to forward the judgement and certificate. ${ }^{42}$ In fact, the issu-

\footnotetext{
36 Ognyanov case, Opinion of $A G$ Bot, par. 150

37 Ddamulira Mujuzi, op. cit. note 31, p. 302

38 Munoz de Morales Romero, M., The role of the European Court of Justice in the execution of sentence, in: Bernardi, A., Prison overcrowding and alternatives to detention, European sources and national legal systems, Napoli, 2016, p. 107

39 Ognyanov case, par. 22

40 Cf. Ddamulira Mujuzi, op. cit. note 29, p. 302

41 Ognyanov case, Opinion of AG Bot, par. 140

42 Munoz de Morales Romero, op. cit. note 38, p. 108
} 
ing state could use transfer as a tool for reducing the number of foreign prisoners by routinely sending them back to their country of origin. ${ }^{43}$

The fact that some MSs have not properly implemented the obligation to provide information upon request before the transfer, ${ }^{44}$ makes the issuing state` $s$ decision on forwarding the judgement more difficult, and it can eventually lead to ineffectiveness of this instrument. FD strives to raise effectiveness of the transfer by providing the possibility that MSs, in deciding on early and conditional release, take into account the relevant provisions of the issuing state.

\section{PROCEDURAL RIGHTS IN TRANSFER PROCEEDINGS}

Another relevant issue regarding the transfer of sentence is the scope of the guaranteed procedural rights and the possibility of their realisation in transfer proceedings. These rights include the right to information on the transfer procedure, the right to interpretation and translation, the right to legal assistance in the issuing and the executing state, the rights concerning the procedure of obtaining the consent or opinion of the person concerned and the right to revoke consent. ${ }^{45}$

The directives adopted under the Stockholm Programme which guarantee procedural rights for the suspects and the accused do not apply to the transfer proceedings under this FD. Even though several proposals to the Directive 2010/64 on the right to interpretation and translation ${ }^{46}$ aimed at ensuring translation of the prison rules, they were not adopted by the Council with the explanation that the rights guaranteed under Art. 6(3) ECHR do not apply per se to the enforcement of a sentence. ${ }^{47}$ Since this Directive, together with the Directive 2012/13 on the right to information ${ }^{48}$ and the Directive $2013 / 48$ on the right to access to a law$\operatorname{yer}^{49}$ do not exclude explicitly the surrender for execution of the sentence from

43 Cf. Klimek, op. cit. note 18, p. 267

44 Report on implementation, op. cit. note 3, p. 9

45 See European Union Agency for Fundamental Rights, Criminal detention and alternatives: fundamental rights aspects in EU crossborder transfers, Luxembourg, 2016, pp. 83 - 98 (Hereinafter: FRA Study) http://fra.europa.eu/en/publication/2016/criminal-detention-and-alternatives-fundamental-rights-aspects-eu-cross-border] Accessed 26 April 2018

46 Directive 2010/64/EU of the European Parliament and of the Council of 22 May 2012 on the right to interpretation and translation in criminal proceedings [2010] OJ L 280/1

47 Cras, S., De Matteis, L., The Directive on the Right to Interpretation and Translation in Criminal Proceedings Genesis and Description, Eucrim 4/2010, p. 158

48 Directive 2012/13/EU of the European Parliament and of the Council of 22 May 2012 on the right to information in criminal proceedings [2010] OJ L 142/1

49 Directive 2013/48/EU of the European Parliament and of the Council of 22 October 2013 on the right of access to a lawyer in criminal proceedings and in European arrest warrant proceedings, and on 
their scope, it may be assumed that they apply to both prosecution and enforcement EAWs. ${ }^{50}$ The situation is different with the Directive 2016/1919 on legal aid for the suspects and the accused which explicitly states that the provisions of the Directive regarding legal aid in the issuing State do not apply to EAWs issued for the purpose of the execution of a sentence. ${ }^{51}$ This is explained by the fact that the requested persons have already had the benefit of access to a lawyer and possibly legal aid during the trial that led to the sentence concerned. ${ }^{52}$

FD on the transfer of prisoners does not address the right of the sentenced person to the interpretation assistance or the translation of proceedings. ${ }^{53}$ Furthermore, it does not provide for a right to legal assistance in the issuing state, and, as far as the executing state is concerned, this right is guaranteed only for the situation when the sentenced person renounces the entitlement to the specialty rule. FD does not address the question of the procedure of obtaining informed consent or opinion or withdrawal of consent, either. Hence, it is on the national law to determine whether it will provide these procedural rights or not in transfer proceedings. ${ }^{54}$ From the recent study it follows that MSs are still in the process of establishing the rules on transferring prisoners and that further safeguards are needed to ensure the overall fairness of the transfer process. In that sense, the procedural Directives could be used as a guidance in establishing the minimum rules for the procedural rights in the transfer proceedings. ${ }^{55}$

Under the Croatian Act on Judicial Cooperation there is no formally established procedure to inform the sentenced person of the option to transfer the judgement and to obtain the informed consent before forwarding the judgement. Informa-

the right to have a third party informed upon deprivation of liberty and to communicate with third persons and with consular authorities while deprived of liberty [2013] OJ L 294/1

50 Marguery, T., van den Brink, T., Simonato, M., Limitations on the obligation of mutual recognition and fundamental rights protection in the EAW, FD 2008/909 and FD 2008/947, in, Marguery, op. cit. note 23, p. 15, p. 19

https://euprisoners.eu/wp-content/uploads/sites/153/2017/11/EUPrisoners-Part-III-limitations-to-MR.pdf] Accessed 26 April 2018

51 Art. 5 Directive 2016/343/EU of the European Parliament and of the Council of 9 March 2016 on the strengthening of certain aspects of the presumption of innocence and of the right to be present at the trial in criminal proceedings [2016] OJ L 65/1

52 Cras, S., The Directive on the Right to Legal Aid in Criminal and EAW Proceedings Genesis and description of the Sixth instrument of the 2009 Roadmap, Eucrim, 2017/1, p. 41-42

53 It only imposes an obligation on the issuing state to inform sentenced persons, in a language they understand, that it has been decided to forward the judgment together with the certificate (Art 6 (4)) and that certificate shall be translated into the official language of the executing sate

54 FRA Study, op. cit. note 45, p. 89

55 Ibid., 98 
tion is provided upon an individual request from the Ministry of Judiciary. ${ }^{56}$ The Act itself does not prescribe the right to legal aid, the right to the assistance of an interpreter and translation. However, the provisions of the subsidiary legislation which provide for these rights (primarily the Criminal Procedure Act) mutatis mutandis apply. The Act does not mention the possibility to revoke the consent, either. According to Krapac, since the consent of the sentenced person represents his own action directly affecting the purpose of the transfer proceedings, in analogy with the relevant provisions of the CPA, valid consent cannot be revoked. ${ }^{57}$ However, concerning the purpose of social rehabilitation, the possibility of withdrawal of consent under certain circumstances should be granted. ${ }^{58}$

In its case law, the Supreme Court referred to procedural rights in the transfer proceedings. It thus emphasised that the provisions of the Act do not foresee the possibility of holding a hearing in the presence of the defence counsel of sentenced person when deciding on the recognition of judgement nor is this procedural action envisaged in the subsidiary law. ${ }^{59}$ Furthermore, the procedural rules of the issuing state law on the basis of which the judgment is rendered are not relevant for the decision on the recognition of a foreign judgment (unless in the event of a trial in absentia) and the domestic court is not authorised to examine such a judgment according to the procedural rules of the Croatian law. ${ }^{60}$

\section{MATERIAL DETENTION CONDITIONS AS OBSTACLE FOR TRANSFER OF PRISONER}

\subsection{Article 4 CFREU/Article 3 ECHR and principle of mutual trust}

One of the open issues in the application of judicial cooperation instruments, particularly in the application of the European Arrest Warrant, is the relationship between the principle of mutual trust and the protection of fundamental human rights, ${ }^{61}$ especially the rights guaranteed in Art. 4 CFREU and Art. 3 ECHR, i.e. the prohibition of torture, and inhuman and degrading treatment. Inadequate detention conditions and overcrowding in some EU member states can undermine

\footnotetext{
56 Country study - Croatia, op. cit. note 28, pp. 7-8

57 Krapac, D., Medunarodna kaznenopravna pomoć, Zagreb, 2006, p. 139. For opposite view of the Supreme Court see ibid.

58 Cf. FRA Study, op. cit. note 45, p. 98

59 Supreme Court of Republic of Croatia, Kž-eun 15/16-8, 22 March 2016

60 Supreme Court of Republic of Croatia, I Kž 186/14-6, 23 April 2014

${ }_{61}$ Cf. Pleić, M., Pritvor u pravu Europske unije, Zbornik radova s međunarodnog znanstvenog savjetovanja "Europeizacija kaznenog prava i zaštita ljudskih prava u kaznenom postupku i postupku izvršenja kaznenopravnih sankcija”, Split, 2017, p. 277
} 
the principle of mutual trust and the effective judicial cooperation between MSs. ${ }^{62}$ It should also be taken into consideration that FD on the transfer of prisoners could cause considerable challenges to the prevention of ill-treatment. ${ }^{63}$

Existing instruments of the third pillar related to the issues of detention do not include the general fundamental rights' non-execution ground for the executing MS, ${ }^{64}$ but nonetheless, several MSs introduced these grounds for non-execution into their implemented legislation. ${ }^{65}$ In the recent years, jurisprudence of CJEU has been showing signs of moving towards the recognition of the grounds for nonexecution on the basis of a breach of the requested person's fundamental rights in the issuing MS. A turning point was made firstly in the area of the common asylum system (N.S. ${ }^{66}$, with the rejection on the part of CJEU of the conclusive presumption of fundamental rights' compliance by the EU MSs, ${ }^{67}$ after which $A G$ Sharpstone in its opinion in Radu case reached the same conclusion in relation to the Area of Freedom, Security and Justice. ${ }^{68}$ Finally, the end of automaticity in judicial cooperation in the criminal matters was confirmed by the CJEU ruling in joint cases Aranyosi and Căldăraru. ${ }^{69}$ The CJEU breakthrough ruling confirmed that mutual trust does not imply blind trust, ${ }^{70}$ thus inserting a subjective element

${ }_{62}$ In the last few years ECtHR identified structural problems in prison systems of several EU MSs, Bulgaria, Romania, Hungary and delivered pilot-judgements. See Neshkov and Others v. Bulgaria (2015) App. No. 36925/10, Varga and Others v. Hungary (2015) App. No. 14097/12, Rezmives, and Others v. Romania (2017) App. No. 61467/12

63 Tomkin, J., Zach, G., Crittin, T., Birk, M., The future of mutual trust and the prvention of ill-treatment, Judicial cooperation and the engagement of national preventive mechanisms, Ludwig Boltzman Institute of Human Rights, 2017, p. 45

'http://bim.lbg.ac.at/sites/files/bim/anhang/publikationen/final_version_the_future_of_mutual_ trust_and_the_prevention_of_ill-treatment_1.pdf] Accessed 6 April 2018

64 Cf. Commission Notice - Handbook on how to issue and execute a European arrest warrant [2017] OJ C 335/01, p. 33. Based on the EAW experience, Directive on European Investigation Order introduced a fundamental rights non-recognition ground. See Erbežnik, A., Mutual Recognition in EU Criminal Law and Fundemental Rights - The Necessity for a Sensitive Approach, in: Brière, C., Weyembergh, A. (eds), The Needed Balances in EU Criminal Law, Past, Present and Future, Hart Publishing, Oxford and Portland, Oregon, 2018, p. 198

65 Marguery et al., op. cit. note 50, p. 10

66 Joined Cases C411/10 and C493/10, N.S. and Others, [2011] ECLI:EU:C:2011:865

67 Mitsilegas, V., The Limits of Mutual Trust in Europe's Area of Freedom, Security and Justice: From Automatic Inter-State Cooperation to the Slow Emergence of the Individual, Yearbook of European Law, Vol. 31, No. 1 (2012), p. 358

68 Case C396/11, Ciprian Vasile Radu [2013] ECLI:EU:C:2013:39. Cf. Pleić, op. cit., note 61, p. 280

69 Joined Cases C404/15 and C659/15 PPU, PálAranyosi and Robert Căldăraru, [2016] EU:C:2016:198

70 van der Mei, A. P., The European Arrest Warrant system: Recent developments in the case law of the Court of Justice, Maastricht Journal of European and Comparative Law 2017, Vol. 24(6), p. 899 [http://journals.sagepub.com/doi/pdf/10.1177/1023263X17745804] Accessed 6 April 2018 
in the surrender procedure. ${ }^{71}$ Nevertheless, the rebuttal of mutual trust can only take place in very exceptional circumstances and under strict conditions. ${ }^{72} \mathrm{CJEU}$ established two-tier test for the executing state to determine whether the surrender to the issuing state would lead to the violation of rights guaranteed in Art. 4 CFREU and to decide whether to refuse the execution of EAW. When there is evidence which demonstrates that there are deficiencies with respect to detention conditions in the issuing MS, the executing judicial authority should determine whether there are substantial grounds to believe that the individual will be exposed to a real risk of inhuman or degrading treatment, and should postpone its decision on the surrender of the individual concerned until it obtains the information that allows it to discount the existence of such a risk. ${ }^{73}$

\subsection{Application of Aranyosi/Căldăraru criteria on transfer proceedings}

In the context of FD on the transfer of prisoners, the concept of mutual trust implies, on the one hand, that the issuing country should have confidence in the the system in force in the executing state before it decides to forward the judgement, and, on the other hand, that the executing state should, unless there are grounds for refusal, recognise the judgement of the issuing state and enforce the custodial sentence. ${ }^{74}$ The European Commission recognised a potential problem with the application of this principle regarding the fact that this FD allows for the transfer without the prisoner's consent of which "may be used to ease overcrowding in one Member State, possibly exacerbating overcrowding in another". ${ }^{75} \mathrm{In}$ the opinion provided in Aranyosi/Căldăraru case, AG Bot concluded that if the existence of a systemic deficiency of detention conditions constitutes ground for the non-execution of EAW, it would also constitute grounds for the non-transfer under FD 2008/909. ${ }^{76}$ Hence, the criteria established in Aranyosi/Căldăraru case are applicable on the transfer proceedings under FD 2008/909 when there is a real risk of inhuman or degrading treatment in the executing MS. But unlike the executing state in EAW, the issuing state in the transfer proceedings has no obligation to transfer, so the tensions between the compliance with the principle of mu-

Anagnostaras, G., Mutual confidence is not blind trust! Fundamental rights protection and the execution of the European arrest warrant: Aranyosi and Căldăraru, Case law, Common Market Law Review, 53, 2016, p 1703

Ibid., p. 1703

Aranyosi/Căldăraru, par. 104

Cf. Marguery et al., op. cit. note 50, p. 12

Green Paper on detention, op. cit. note 30, p. 6

Joined Cases C404/15 and C659/15 PPU, Pál Aranyosi and Robert Căldăraru, Opinion of Advocate General Bot [2016] ECLI:EU:C:2016:140, par. 128 
tual recognition and the respect for human rights will be less pronounced. ${ }^{77}$ The major responsibility regarding the assessment of possible infringement of human rights is on the issuing authority which should, before deciding on forwarding the judgement, conduct a two-step analysis, ${ }^{78}$ and very carefully assess the detention conditions and all other potential risk factors that may cause the violation of Article $3 \mathrm{ECHR} / 4$ CFREU. The prisoner's opinion and the consultations with the executing MS play a very important role here, but, notwithstanding their opinion, the issuing MS itself should investigate all relevant elements by using available sources (reports from the European Committee for the prevention of torture, ECtHR jurisprudence, jurisprudence of national courts). ${ }^{79}$ The problem may occur if the issuing MS also has problems with overcrowding and uses the transfer of prisoners as a mechanism to ease the situation in its own prison system. In these circumstances it is questionable whether the issuing MS will undertake this analysis "specifically and precisely" as CJEU requires.

The other issue is related to the position of the executing MS. The question is whether there is a possibility for the executing MS to refuse the recognition of the judgement if it faces systematic deficiencies of the prison system. According to Aranyosi/Căldăraru judgement, the answer is affirmative, but the other question is if it would be in the interest of ES to do so because by referring to inadequate conditions in its prison system, it would imply that it admits the violation of an absolute human right.

We can analyse this situation from the prisoner's position also, i.e. his opportunities to invoke the violation of Article 3 ECHR. Here, the question is whether the prisoner has an opportunity to state his complaints regarding the possible violation of Article 3 ECHR and whether it will have actual effect. Considering the fact that the prisoner's consent, as well as his opinion are not in all situations required for the transfer, and also that FD 2008/909 does not provide for the right to appeal the forwarding decision in the issuing state, it is obvious that the prisoner will not have in all cases the opportunity to file a complaint concerning the inadequate conditions of detention in the executing state.

\subsection{Detention conditions in Croatian prison system - small step forward}

Inadequate detention conditions and overcrowding have been encumbering the prison system of Republic of Croatia for a long time, but recently, for about last four

Marguery, op. cit. note 23, p. 5

78 Cf. Munoz de Morales Romero, op. cit. note 38, p. 98

79 Aranyosi/Căldăraru case, par. 104 
years, the situation has been improving. ${ }^{80}$ Over the past ten years, the Croatian penitentiary law has been developing mostly under the influence of the jurisprudence of the European Court of Human Rights, and the Constitutional Court of Republic of Croatia. ${ }^{81}$ ECtHR has so far found the violation of Art. 3 ECHR due to inadequate detention conditions in the Croatian prison system in seven judgements, ${ }^{82}$ and the most recent was delivered in 2016 in the case Muršić v Croatia. $^{83}$

Unlike in some other EU countries, the problem of prison overcrowding in Croatia was not enhanced by the number of foreign prisoners (especially the number of EU prisoners) which is relatively insignificant and does not raise the question over the possible hidden agenda behind the transfer. ${ }^{84}$

In terms of the criteria set up in Aranyosi/Căldăraru case, Croatia should not have an issue with systematic deficiencies of the prison system, but the deficiencies in specific penitentiary institutions should, nevertheless, be considered. Even though overcrowding has been diminishing in the recent years, the situation in the prison system is far from desirable. There is a big difference in the prison occupancy rate in high security, semi-security and minimum security penitentiary institutions, ${ }^{85}$ and this kind of information should be made available to the issuing state authority (upon its request) when deciding on forwarding the certificate to the Republic of Croatia.

80 From 2008 to 2013, the prison population rate of overcrowding was recorded, and since 2014 there has been a significant and constant decrease in the prison population rates. Aebi, M. F., Tiago, M. M., Burkhardt, C., SPACE I - Council of Europe Annual Penal Statistics: Prison populations. Survey 2015. Strasbourg: Council of Europe, 2016, 'http://wp.unil.ch/space/files/2017/04/SPACE_I_2015_FinalReport_161215_REV170425.pdf] Accessed 27 April 2018

81 See Ivičević Karas, E., Ljudska prava i temeljne slobode u hrvatskom penitencijarnom pravu, in: Krapac, D. (ed), Profili hrvatskog kaznenog zakonodavstva, Zagreb, 2014, p. 180

82 For detailed analysis of these judgements see Pleić, M., Zabrana mučenja u praksi Europskog suda za ljudska prava s posebnim osvrtom na presude protiv Republike Hrvatske i praksu Ustavnog suda RH, Hrvatski ljetopis za kaznene znanosti i praksu (Zagreb), vol. 23, broj 2/2016, pp. 261-265

83 Muršićv Croatia (2016) App. No. 7334/13. The Court found that notwithstanding the conditions in Bjelovar Prison were generally appropriate, that there had been a violation of Art. 3 for the consecutive period of 27 days during which applicant had been confined in less than $3 \mathrm{~m} 2$ of personal space. Muršić, par. 172

84 On 31 December 2016 there were 228 persons in the prison system (216 men and 12 women) who were not Croatian citizens. Out of the total number of foreign prisoners (228), only 37 were EU citizens

85 The occupancy level on the 31 December 2016 was $93,91 \%$ in high security conditions, $57,1 \%$ in semi-security and $38,95 \%$ in minimum security conditions. Vlada Republike Hrvatske, Izvješće o stanju i radu kaznionica, zatvora i odgojnih zavoda za 2016. godinu, Zagreb, 2017, p. 13

https://pravosudje.gov.hr/pristup-informacijama-6341/strategije-planovi-i-izvjesca/izvjesce-o-stanju-i-radu-kaznionica-zatvora-i-odgojnih-zavoda/6720] Accessed 27 April 2018 
When it comes to the decision of our judicial authorities to forward the certificate to another MS, the Act on Judicial Cooperation does not take into consideration the implications of the decision on the fundamental rights. Nevertheless, the court should take under consideration the prison conditions in the executing state prior to forwarding a judgement, ${ }^{86}$ in accordance with CJEU case law. In view of the above, it is necessary that all relevant information (regarding the situation in the prison system and the jurisprudence of national courts) is available, updated, reliable and precise in accordance with Aranyosi/Căldăraru criteria, and that all competent authorities are familiar with the established procedure and coordinated in their work. This particularly applies to the cooperation of competent courts with the Prison administration.

\section{LINK BETWEEN FD ON TRANSFER OF PRISONERS AND FDEAW}

FDEAW and FD on the transfer of prisoners have different functions and purpose but they interplay with each other, notably in the part in which FD EAW can involve the transfer of the sentenced person. ${ }^{87} \mathrm{FD}$ EAW includes the provisions (Art. 4(6) and 5(3)) that enable the execution of a sentence in the place where the requested person resides instead in the issuing MS which conducted the trial. As CJEU emphasised, these provisions have "the objective of enabling particular weight to be given to the possibility of increasing the requested person's chances of reintegrating into society." 88 According to Art. 25 of FD 2008/909, this FD applies mutatis mutandis to the enforcement of sentences in the cases under Art. 4(6) and 5(3) of FDEAW to the extent that they are compatible with the provisions under FDEAW. ${ }^{89}$

The transfer of prisoners under FD 2008/909 can be used in relation to EAW in two different ways: as a substitute mechanism for EAW (replacing the issuance of EAW or, once it has been issued, replacing the execution of EAW) and as a complementary mechanism to the EAW (precondition for the execution of EAW).

\subsection{Articles 4(6) and 5(3) of FD EAW and CJEU case law}

FD on the transfer of prisoners as a substitute mechanism is used for the purpose of serving the sentence in the place where the sentenced person resides instead of

\footnotetext{
${ }_{86}$ Country study - Croatia, op. cit. note 28, p. 15

87 Cf. Marguery et al., op. cit. note 50, p. 6

88 Case C-306/09, I.B., [2010] ECLI:EU:C:2010:626, par. 52

89 But not all MSs implemented this provision. See Report on the implementation, $o p$. cit. note 3, p. 11
} 
the surrender of the person to the MS where the sentence was handed down..$^{90}$ Instead of issuing EAW for the purposes of executing a custodial sentence, the issuing MS can, under FD 2008/909, initiate the transfer of a person who resides in the executing MS, on its own initiative or on the initiative of the executing member state or the sentenced person.

In the situations when the issuing MS has already issued EAW and the requested person is staying in, or is a national or a resident of the executing member state, FDEAW allows for the executing MS to undertake the execution of the sentence in accordance with its domestic law (Article 4(6)). In this situation, it is on the executing MS to decide whether it will undertake the execution of the sentence according to $\mathrm{FD}$ on the transfer of prisoners or surrender the requested person to the issuing MS. ${ }^{91}$

The transfer of prisoners under FD 2008/909 can also be used as a complementary mechanism to EAW for returning the nationals and residents to serve their sentence in their home country once the criminal procedure has been completed in the issuing MS. In this case, the transfer of the requested person to the executing MS is a precondition for the execution of EAW issued for the purposes of prosecuting a national or a resident of the executing MS. The idea behind this guarantee is not only to safeguard the sovereignty of the executing State over its nationals and residents but to favour their resocialisation after the sentence has been served. ${ }^{92}$

CJEU had the opportunity to decide on the interpretation of Art. 4(6) and 5(3) in several cases (Kozlowski, ${ }^{93}$ Wolzenburg, ${ }^{94}$ Lopes da Silva Jorge, ${ }^{95}$ I.B.) and most recently in Poplawski case. ${ }^{96}$ In its rulings, CJEU has over time made a step forward from the focus on the efficacy in cooperation, and placed the principle of reintegration behind the perspective of the protection of human rights. ${ }^{97}$

Handbook on EAW, op. cit. note 64, p. 16

Ibid., p. 31

Klimek, L., European Arrest Warrant, Springer, 2015, p. 167

Case C-66/08, Szymon Koztowski [2008] ECLI:EU:C:2008:437

Case C123/08, Dominic Wolzenburg [2009] ECLI:EU:C:2009:616

Case C42/11, João Pedro Lopes Da Silva Jorge, [2012] ECLI:EU:C:2012:517

C579/15, Daniel Adam Poptawski [2017] ECLI:EU:C:2017:503

See Munoz de Morales Romero, op. cit. note 38, p. 78. In Koztowski the CJEU gave somewhat strict interpretation of terms 'resident' and 'staying' under Article 4(6) and in Wolzenburg concluded that indefinite residence permit cannot be requirement for the possibility to refuse execution of EAW but allowed for the national law to subject the refusal to the condition that that person has lawfully resided for a continuous period of five years in that MS of execution. From Lopes da Silva Jorge case follows that MS cannot automatically and absolutely exclude from the scope of the Art. 4(6) the nationals of other 
The link between the refusal of execution of EAW and the transfer of a sentence can give rise to practical problems, considering that these two instruments are not fully compatible. Certain grounds for refusal from FD 2008/909 could potentially lead to the impossibility to take over the sentence in the executing state. ${ }^{98}$ The problem could also arise if the executing MS, having given the guarantee, would no longer be willing to receive the person. ${ }^{99}$ The problem of this kind was addressed recently in Poplawski case. CJEU stated that the mere fact that the executing MS declares itself willing to execute the sentence does not suffice for the refusal of execution of EAW but it must examine whether it is actually possible to execute the sentence. Also, the important thing is that the authorities of the executing state have a certain margin of discretion when deciding on the refusal under Art. 4(3) FDEAW. ${ }^{100}$

\subsection{Implementation of Articles 4(6) and 5(3) of FD EAW in Croatian law}

Article 22 of the Act on Judicial Cooperation laid down special conditions for the execution of EAW by implementing Articles 4(6) and 5(3) of FDEAW. Before the amendments to the Act of 2015, these conditions were prescribed in Article 22a but only with respect to the Croatian citizens who reside in the Republic of Croatia. In order to align with the CJEU case law, the Croatian legislator extended the scope of application of Article 22 onto Croatian nationals regardless of their residence, and to non-nationals who reside in or who are domiciled in the Republic of Croatia. ${ }^{101}$ Furthermore, the specific provision relating to the surrender of a person sentenced in absentia is added. The application of Article 22 (22a) revealed some disputable moments, particularly regarding the question how to proceed in cases where the competent authority of the issuing state refuses to provide the required documentation or when there is no interest of that authority to forward the certificate to the competent court of the Republic of Croatia. ${ }^{102}$ The Supreme

MS staying or resident in its territory irrespective of their connections with it. According to ruling in I.B. case condition contained in Art. 5(3) is applicable in the situation of a person who was sentenced in absentia and to whom it is still open to apply for a retrial. I.B., par. 56-57

98 Klimek, op. cit., note 18, p. 288

$99 \quad$ Ibid.

100 van der Mei, op. cit. note 70, p. 895. Poplawski case, par. 23. Furthermore, CJEU stated that Article 4(6) of FD EAW does not authorise a MS to refuse to execute an EAW on the sole ground that that Member State intends to prosecute that person in relation to the same acts as those for which that judgment was pronounced. Ibid., par. 49

101 See Vlada Republike Hrvatske, Konačni prijedlog Zakona o izmjenama i dopunama Zakona o pravosudnoj suradnji u kaznenim stvarima s državama članicama Europske unije, Zagreb, 2015, p. 28, [https:// vlada.gov.hr/UserDocsImages//Sjednice/2015/206\%20sjednica\%20Vlade//206\%20-\%202.pdf] Accessed 27 April 2018

102 Krbec, op. cit. note 17, p. 419 
Court confirmed that in this kind of situation the first instance court could refuse the execution of EAW irrespective of the fact that the execution of a foreign judgement has not been carried out. ${ }^{103}$ It is important to underline that the requested person has to be informed about his or her right to have the sentence served in the Republic of Croatia, otherwise his or her consent for surrender will be invalid. ${ }^{104}$

\section{CONCLUDING REMARKS}

The Framework decision on the transfer of prisoners is an instrument intended to extend the principle of mutual recognition to judgements that impose custodial sentences, but this objective has not been fully achieved. ${ }^{105}$ Slow implementation of this FD and of other complementary FDs, as well as little practical experience in their application point to the level of concern for the detention issues and prisoners' rights in the EU member states.

Even though social rehabilitation is inherent to the principle of mutual recognition, these two principles, as we could see, may collide. The question of consent of the sentenced person to the transfer is the focal issue of the scientific and expert discussions over the objectives and operation of this instrument. The possibility of transfer without the consent enables an effective and rapid application of the principle of mutual recognition of judgements imposing custodial sentences, but at the same time it reduces the possibilities of pursuing the aim of social rehabilitation of the sentenced person in circumstances of such forced transfer.

Non-consenting transfer becomes even more arguable when the protection of fundamental rights, such as the prohibition of inhuman and degrading treatment comes into question. In circumstances where consent and opinion of the sentenced person are not required, the risk of violation of this right is much greater.

CJEU ruling in Aranyosi/Căldăraru case, which confirmed that mutual trust is not blind trust, has far-reaching implications for the functioning of not only EAW but also of the other instruments of judicial cooperation in ASFJ. In the transfer proceedings, the issuing authority is primarily responsible for the assessment of social rehabilitation and for the assessment of possible violations of fundamental rights in accordance with Aranyosi/Căldăraru criteria.

\footnotetext{
103 Supreme Court of Republic of Croatia, Kž eun 41/2014-4, 23 September 2014

104 The requested person must be "fully aware of all consequences" of consent and one of the consequences of consent under article 22(4) is her right to serve the sentence in Republic of Croatia. Supreme Court of Republic of Croatia, Kž-eun 28/2016-4, 6 June 2016

105 See Klimek, op. cit. note 18, p. 295
} 
Furthermore, it is important to emphasise the connection between the operation of FD on the transfer of prisoners and FDEAW, i.e. possibilities of the enforcement of the sentence following EAW which purports social rehabilitation. Even though the CJEU case law in this issue moved from the functionalist towards the perspective of protection of human rights, the effectiveness of the principle of mutual recognition still prevails over the tendency to facilitate social rehabilitation.

Analysis and comparison of national legislation and practice with the EU legislation and case law is a necessary precondition for the improvement of the Croatian judicial cooperation in criminal matters with the EU members. The presented analysis of some arguable issues regarding FD on the transfer of prisoners and the recent and relevant case law of CJEU shows that the Croatian legislator in general pursues the objectives of the EU law, but not without practical problems. In that sense, the focus should be on the research that indicates the need to establish firm and fair procedural guarantees and the recent ECJEU case law which imposes strict requirements for the competent national authorities in relation to the procedure, gathering information, cooperation with other competent authorities on the national and EU level.

\section{REFERENCES}

\section{BOOKS AND ARTICLES}

1. Ambrož, M., Transfer zapornikov znotraj EU - res v imenu socialne reintegracije? Revija za kriminalistiko in kriminologijo, Ljubljana, 63, 2012, 3, pp. 191-198

2. Anagnostaras, G., Mutual confidence is not blind trust! Fundamental rights protection and the execution of the European arrest warrant: Aranyosi and Căldăraru, Case law, Common Market Law Review, 53, 2016, pp. 1675-1704

3. Cras, S., The Directive on the Right to Legal Aid in Criminal and EAW Proceedings Genesis and description of the Sixth instrument of the 2009 Roadmap, Eucrim, 2017/1, pp. 34-44

4. Cras, S., De Matteis, L., The Directive on the Right to Interpretation and Translation in Criminal Proceedings Genesis and Description, Eucrim 4/2010, pp. 153-162

5. Ddamulira Mujuzi, J., The Transfer of Offenders between European Countries and Remission of Sentences: A Comment on the Grand Chamber of the Court of Justice of the European Union's Judgment in Criminal Proceedings against Atanas Ognyanov of 8 November 2016 Dealing with Article 17 of Council Framework Decision 2008/909/JHA, European Criminal Law Review, Volume 7 (2017), pp. 289-303

6. De Bondt, W., Suominen, A., State Responsibility When Transferring Non-consenting Prisoners to Further their Social Rehabilitation - Lessons Learnt from the Asylum Case Law, European Criminal Law Review, 5(3) 2016, pp. 347-370

7. De Wree, E., Vander Beken, T., Vermeulen, G., The transfer of sentenced persons in Europe: Much ado about reintegration, Punishment Society, 2009, 11, pp. 111-128 
8. Erbežnik, A., Mutual Recognition in EU Criminal Law and Fundemental Rights - The Necessity for a Sensitive Approach, in: Brière, C., Weyembergh, A. (eds): The Needed Balances in EU Criminal Law, Past, Present and Future, Hart Publishing, Oxford and Portland, Oregon, 2018, pp. 185-211

9. Garačić, A., Zakon o pravosudnoj suradnji u kaznenim stvarima s državama članicama Europske unije u sudskoj praksi, Rijeka, 2015

10. Ivičević Karas, E., Ljudska prava i temeljne slobode u hrvatskom penitencijarnom pravu, in: Krapac, D. (ed), Profili hrvatskog kaznenog zakonodavstva, Zagreb, 2014, pp. 175-205

11. Klimek, L., European Arrest Warrant, Springer, 2015

12. Klimek, L., Mutual Recognition of Judicial Decisions in European Criminal Law, Springer, 2017

13. Krapac, D., Međunarodna kaznenopravna pomoć, Zagreb, 2006

14. Krbec, I., Priznanje i izvršenje stranih odluka prema Zakonu o pravosudnoj suradnji u kaznenim stvarima s državama članicama Europske unije, Hrvatski ljetopis za kazneno pravo i praksu (Zagreb), vol. 21, broj 2/2014, pp. 401-438

15. Mitsilegas, V., The Limits of Mutual Trust in Europe's Area of Freedom, Security and Justice: From Automatic Inter-State Cooperation to the Slow Emergence of the Individual, Yearbook of European Law, Vol. 31, No. 1 (2012), pp. 319-372

16. Munoz de Morales Romero, M., The role of the European Court of Justice in the execution of sentence, in: Bernardi, A., Prison overcrowding and alternatives to detention, European sources and national legal systems, Napoli, 2016, pp. 67-112

17. Pleić, M., Pritvor u pravu Europske unije, Zbornik radova s međunarodnog znanstvenog savjetovanja "Europeizacija kaznenog prava i zaštita ljudskih prava u kaznenom postupku i postupku izvršenja kaznenopravnih sankcija”, Split, 2017, pp. 265-290

18. Pleić, M., Zabrana mučenja u praksi Europskog suda za ljudska prava s posebnim osvrtom na presude protiv Republike Hrvatske i praksu Ustavnog suda RH, Hrvatski ljetopis za kaznene znanosti i praksu (Zagreb), vol. 23, broj 2/2016, pp. 247-249

\section{EU LAW}

1. Charter of Fundamental Rights of the European Union [2012] OJ C 326

2. Commission Notice - Handbook on how to issue and execute a European arrest warrant [2017] OJ C 335/01

3. Council Framework Decision 2002/584/JHA of 13 June 2002 on the European arrest warrant and the surrender procedures between Member States [2002] OJ L 190

4. Council Framework Decision 2008/909/JHA on the application of the principle of mutual recognition to judgments imposing custodial sentences or measures involving deprivation of liberty [2008] OJ L 327

5. Council Framework Decision 2008/947/JHAon the application of the principle of mutual recognition of probation decisions and alternative sanctions [2008] OJ L 337

6. Council Framework Decision 2009/829/JHA on the application of the principle of mutual recognition to decisions on supervision measures as an alternative to provisional detention [2009] OJ L 294 
7. Directive 2010/64/EU of the European Parliament and of the Council of 22 May 2012 on the right to interpretation and translation in criminal proceedings [2010] OJ L 280/1

8. Directive 2012/13/EU of the European Parliament and of the Council of 22 May 2012 on the right to information in criminal proceedings [2010] OJ L 142/1

9. Directive 2013/48/EU of the European Parliament and of the Council of 22 October 2013 on the right of access to a lawyer in criminal proceedings and in European arrest warrant proceedings, and on the right to have a third party informed upon deprivation of liberty and to communicate with third persons and with consular authorities while deprived of liberty [2013] OJ L 294/1

10. Directive 2016/343/EU of the European Parliament and of the Council of 9 March 2016 on the strengthening of certain aspects of the presumption of innocence and of the right to be present at the trial in criminal proceedings [2016] OJ L 65/1

11. European Commission, Strengthening mutual trust in the European judicial area - A Green Paper on the application of EU criminal justice legislation in the field of detention, COM (2011) 327 final, Brussels, 14.6.2011

12. Report from the Commission to the European Parliament and the Council on the implementation by the Member States of the Framework Decisions 2008/909/JHA, 2008/947/ JHA and 2009/829/JHA on the mutual recognition of judicial decisions on custodial sentences or measures involving deprivation of liberty, on probation decisions and alternative sanctions and on supervision measures as an alternative to provisional detention, COM (2014) 57 final, Brussels, 5.2.2014

\section{COURT OF JUSTICE OF THE EUROPEAN UNION}

1. Case C123/08, Dominic Wolzenburg [2009] ECLI:EU:C:2009:616

2. Case C289/15, Jozef Grundza [2017] ECLI:EU:C:2017:4

3. Case C-306/09, I.B., [2010] ECLI:EU:C:2010:626

4. Case C396/11, Ciprian Vasile Radu [2013] ECLI:EU:C:2013:39

5. Case C42/11, João Pedro Lopes Da Silva Jorge, [2012] ECLI:EU:C:2012:517

6. Case C-554/14, Atanas Ognyanov [2016] ECLI:EU:C:2016:835

7. Case C-554/14, Atanas Ognyanov, Opinion of Advocate General Bot [2016] ECLI:EU:C:2016:319

8. Case C579/15, Daniel Adam Poptawski [2017] ECLI:EU:C:2017:503

9. Case C582/15, Gerrit van Vemde [2017] ECLI:EU:C:2017:37

10. Case C-66/08, Szymon Koztowski [2008] ECLI:EU:C:2008:437

11. Joined Cases C404/15 and C659/15 PPU, Pál Aranyosi and Robert Căldăraru, [2016] EU:C:2016:198

12. Joined Cases C404/15 and C659/15 PPU, Pál Aranyosi and Robert Căldăraru, Opinion of Advocate General Bot [2016] ECLI:EU:C:2016:140

13. Joined Cases C411/10 and C493/10, N.S. and Others, [2011] ECLI:EU:C:2011:865 


\section{ECHR}

1. Muršić v Croatia (2016) App. No. 7334/13

2. Neshkov and Others v. Bulgaria (2015) App. No. 36925/10

3. Rezmives, and Others $v$. Romania (2017) App. No. 61467/12

4. Varga and Others v. Hungary (2015) App. No. 14097/12

\section{LIST OF NATIONAL REGULATIONS, ACTS AND COURT DECISIONS}

1. Act on Judicial Cooperation in Criminal Matters with Member States of the European Union, Official Gazette 91/10, 81/13, 124/13, 26/15, 102/17

2. Criminal Procedure Act, Official Gazette $152 / 2008,76 / 2009,80 / 2011,91 / 2012,143 / 2012$, 56/2013, 145/2013, 152/2014, 70/2017

3. Supreme Court of Republic of Croatia, I Kž 186/14-6, 23 April 2014

4. Supreme Court of Republic of Croatia, Kž eun 41/2014-4, 23 September 2014

5. Supreme Court of Republic of Croatia, Kž-eun 15/16-8, 22 March 2016

6. Supreme Court of Republic of Croatia, Kž-eun 28/2016-4, 6 June 2016

\section{WEB REFERENCES}

1. Aebi, M. F., Tiago, M. M., Burkhardt, C., SPACE I - Council of Europe Annual Penal Statistics: Prison populations. Survey 2015. Strasbourg: Council of Europe, 2016, [http://wp.unil. ch/space/files/2017/04/SPACE_I_2015_FinalReport_161215_REV170425.pdf] Accessed 27 April 2018

2. Durnescu, I., Montero Perez de Tudela, E., Ravagnani, L., Prisoner transfer and the importance of 'release effect', Criminology \& Criminal Justice Vol 17, Issue 4, pp. 450 - 467.

[http://www.cep-probation.org/paper-prisoner-transfer-and-the-importance-of-release-effect/] Accessed 26 April 2018

3. European Judicial Network, Status of implementation of Council Framework Decision 2008/909/JHA of 27 November 2008,

[https://www.ejn-crimjust.europa.eu/ejn/EJN_library_statusOfImpByCat. aspx?CategoryId=36] Accessed 29 March 2018

4. European Union Agency for Fundamental Rights, Criminal detention and alternatives: fundamental rights aspects in EU crossborder transfers, Luxembourg, 2016,

[http://fra.europa.eu/en/publication/2016/criminal-detention-and-alternatives-fundamental-rights-aspects-eu-cross-border] Accessed 26 April 2018

5. European Union Agency for Fundamental Rights, Country study for the project on Rehabilitation and mutual recognition - practice concerning EU law on transfer of persons sentenced or awaiting trial- Croatia, May 2015

[http://fra.europa.eu/en/country-data/2016/country-studies-project-rehabilitation-andmutual-recognition-practice-concerning] Accessed 26 April 2018

6. Marguery, T., Part VI Conclusions and Recommendations, in Marguery, T. (ed), Mutual Trust under Pressure, the Transferring of Sentenced Persons in the EU, Transfer of Judgments of 
Conviction in the European Union and the Respect for Individual's Fundamental Rights, 2018,

[https://euprisoners.eu/wp-content/uploads/sites/153/2017/11/EUPrisoners-Part-VI-Conclusions-and-recommendations.pdf] Accessed 26 April 2018

7. Marguery, T., van den Brink, T., Simonato, M., Limitations on the obligation of mutual recognition and fundamental rights protection in the EAW, FD 2008/909 and FD 2008/947, in Marguery, T. (ed), Mutual Trust under Pressure, the Transferring of Sentenced Persons in the EU, Transfer of Judgments of Conviction in the European Union and the Respect for Individual's Fundamental Rights, 2018,

[https://euprisoners.eu/wp-content/uploads/sites/153/2017/11/EUPrisoners-Part-III-limitations-to-MR.pdf] Accessed 26 April 2018

8. Meysman, M., Council Framework Decisions 2009/829/JHA, 2008/909/JHA and 2008/947/ JHA and their implementation: state of play and overcoming legal and practical problems, Academy of European Law -Improving conditions related to detention The role of the ECHR, the Strasbourg court and national courts, 25-26 February 2016, Strasbourg, ERA, [https://biblio.ugent.be/publication/7136169] Accessed 26 April 2018

9. Montaldo, S., Judicial Cooperation, Transfer of Prisoners and Offenders' Rehabilitation: No Fairy-tale Bliss. Comment on Ognyanov, European Papers, Vol. 2, 2017, N0 2

[http://www.europeanpapers.eu/en/europeanforum/judicial-cooperation-transfer-of-prisoners-offenders-rehabilitation-comment-on-ognyanov] Accessed 26 April 2018

10. Notification by Croatia on the implementation of the Framework Decision on Transfer of prisoners, 12335/14, Brussels, 17 September 2014,

[https://www.ejn-crimjust.europa.eu/ejn/libdocumentproperties.aspx?Id=1386] Accessed 26 April 2018

11. Tomkin, J., Zach, G., Crittin, T., Birk, M., The future of mutual trust and the prvention of illtreatment, Judicial cooperation and the engagement of national preventive mechanisms, Ludwig Boltzman Institute of Human Rights, 2017

[http://bim.lbg.ac.at/sites/files/bim/anhang/publikationen/final_version_the_future_of_ mutual_trust_and_the_prevention_of_ill-treatment_1.pdf] Accessed 6 April 2018

12. van der Mei, A. P., The European Arrest Warrant system: Recent developments in the case law of the Court of Justice, Maastricht Journal of European and Comparative Law 2017, Vol. 24(6) [http://journals.sagepub.com/doi/pdf/10.1177/1023263X17745804] Accessed 6 April 2018

13. Vlada Republike Hrvatske, Izvješće o stanju i radu kaznionica, zatvora i odgojnih zavoda za 2016. godinu, Zagreb, 2017

[https://pravosudje.gov.hr/pristup-informacijama-6341/strategije-planovi-i-izvjesca/izvjesce-o-stanju-i-radu-kaznionica-zatvora-i-odgojnih-zavoda/6720] Accessed 27 April 2018

14. Vlada Republike Hrvatske, Konaćni prijedlog Zakona o izmjenama i dopunama Zakona o pravosudnoj suradnji u kaznenim stvarima s državama članicama Europske unije, Zagreb, 2015 [https://vlada.gov.hr/UserDocsImages//Sjednice/2015/206\%20sjednica\%20 Vlade//206\%20-\%202.pdf] Accessed 27 April 2018

15. Working Group Report, 9 May 2016, Brussels, Belgium, EuroPris FD 909 Expert Group, [http://www.europris.org/file/europris-framework-decision-909-expert-group/] Accessed 27 April 2018 